\title{
METODE DAN MATERI DAKWAH UNTUK WANITA BERMASALAH
}

\author{
Umul Baroroh \\ Pasca Sarjana Universitas Islam Negeri Walisongo \\ Email: Ummul.bararah@walisongo.ac.id
}

\begin{abstract}
Today, along with the pace of information growth, technology raises increasingly complex social problems. The complexity of the problems faced by humans increases and cones like a mountain. For those who are able to overcome social problems will not create new problems. Conversely, for people who are not able to adapt to the development of the times will have new problems. In today's modern era many women have problems that make it one of the "victims" of the progress of the age. This short article elaborates on the methods and material of Dakwah in dealing with problems for women involved in life issues. Analysis of this article states that returning to Dakwah methods and material adapted to al quran and hadith is a panacea that can solve their problems
\end{abstract}

Dewasa ini, seiring dengan laju pertumbuhan informasi, teknologi memunculkan persoalan sosial yang semakin komplek. Kompleksitas persoalan yang dihadapi manusia bertambah dan mengerucut seperti gunung. Bagi mereka yang mampu mengatasi masalah sosial tidak akan memunculkan persoalan baru. Sebaliknya, bagi masyarakat yang tidak mampu adaptasi dengan perkembangan zaman akan mempunyai persoalan baru. Di era modern sekarang ini wanita banyak mempunyai persoalan yang menjadikannya sebagai salah satu "korban" atas kemajuan zaman. Artikel singkat ini mengelaborasikan tentang metode dan materi dakwah dalam menghadapi persoalan bagi wanita yang terlibat dalam persolan kehidupan. Analisa artikel ini menyatakan bahwa kembali kepada metode dan materi dakwah yang disesuaikan dengan al qur'an dan hadits merupakan obat mujarab yang dapat menyelesaikan persoalan mereka.

Kata Kunci: Metode Dakwah, Materi Dakwah, Wanita Bermasalah

\section{A. Latar Belakang}

Walapun telah banyak menghasilkan kemajuan diberbagai bidang kehidupan, pembangunan yang dilaksanakan di Indonesia selama ini juga telah mempunyai dampak negatif yang cukup berarti. Diantara dampak negataif tersebut adalah tereksploitasinya sumber daya hayati secara tak terkontrol yang telah menghancurkan lingkungan hidup, terutama di desa-desa. Sementara itu, kehidupan kota yang lebih banyak menikmati hasil pembangunan telah menarik masyarakat pedesaan sehingga banyak diantara mereka berbondongbondong menuju kota untuk ikut menikmati hasil pembangunan. Namun 
demikian, kurang meratanya hasil tersebut yang diakibatkan oleh dominasi kelompok kecil elit di perkotaan menyebabkan kedatangan sebagian penduduk pedesaan tersebut hanya menambah kelompok miskin di perkotaan. ${ }^{1}$ Kesenjangan sosial ekonomi antara yang kaya dan miskin semakin lebar. Dampak negatif pembangunan tersebut diantaranya disebabkan oleh rendahnya kualitas sebagian besar sumber daya manusia yang tersedia.

Kemajuan yang cukup pesat dikota yang didukung oleh kemajuan ilmu pengetahuan dan teknologi telah membuat kehidupan semakin mudah. Hal ini merangsang masyarakat untuk berusaha ikut menikmati kemajuan tersebut. Keinginan tersebut semakin kuat, diantaranya dengan gencarnya iklan berbagai kemudahan yang disebarkan melalui media massa, baik cetak maupun elektronik. Keinginan untuk menikmati kemudahan tersebut menurut yang bersangkutanuntuk mendapatkan penghasilan yang cukup, yang hanya diperoleh melalui kerja keras. Tuntutan tersebut tidak hanya menimpa kaum pria, yang secara tradisional bertanggung jawab atas pemenuhannya, tetapi juga kaum wanita, yang dengan adanya kemajuan talah bertanggung jawab pula untuk pemenuhan tersebut.

Keterlibatan wanita dalam usaha pemenuhan kebutuhan tersebut, disatu sisi telah mengangkat derajat mereka setara dengan kaum pria dalam kancah sosial, tetapi di sisi lain justru menambah berat beban yang harus dipikulnya. Hal ini karena disamping memikul tanggung jawab bersama kaum pria, mereka masih tetap dibebani dengan tanggung jawab tradisional untuk mengurus rumah tangga. ${ }^{2}$ Bertambahnya beban yang harus dipikul oleh wanita ini menyebabkan mereka menghadapi permasalahan sosial yang menekan kehidupan mereka sehingga menimbulkan stres, yang oleh Djalaludin Rahmat disebut sebagai penyakit modernitas. ${ }^{3}$ Penyakit ini merupakan biaya ekonomi dan sosial serta psikologis yang harus dibayar untuk mencapai modernitas tersebut. Akibatnya, dengan meningkatnya tanggung jawab wanita, semakin besar pula permasalahan yang dihapi oleh wanita.

Untuk mengatasi permasalahan tersebut, wanita memerlukan bantuan, yang salah satunya diharapkan dapat dipenuhi oleh dakwah islam. Tentu saja, dakwah islam yang dapat memenuhi kebutuhan tersebut harus sesuai dengan permasalahan yang dihadapi wanita, baik darai segi metode maupun materinya. Yang jadi pertanyaan adalah metode dan materi dakwah yang bagaimanakah yang sesuai untuk para wanita yang menghadapi permasalahan sosial dalam era modernisasi saat ini? Artikel ini akan berusaha untuk menjawab pertanyaan tersebut. Akan tetapi, sebelum membahas tersebut

\footnotetext{
${ }^{1}$ Julia Clave, Gender dan pembangunan, Yogyakarta: Pustaka Pelajar, 1996, hlm. 13

${ }^{2}$ Ibid, hlm 81, Kartini Kartono dan Jenny Andani, Hygiene dan Kesehatan Mental dalam Islam, Bandung: Mandar Maju,

${ }^{3}$ Djalaludin Rahmat, Islam Aktual, Bandung: Mizan, 1984, Hal 115
} 
terlebih dahulu artikel ini akan membahas permasalahan sosial dan faktor yang menyebabkanya.

\section{B. Faktor Permasalahan Sosial}

Masalah sosial tidak muncul dengan sendirinya, tetapi karena adanya faktor yang mempengaruhinya. Masalah tersebut muncul sebagai akibat dari adanya ketidaksehatan mental seseorang atau sekelompok masyarakat. Ketidaksehatan mental tersebut, menurut Kartini Kartono ${ }^{4}$, disebabkan terjadinya konflik-konflik batin yang serius karena adanya faktor-faktor sebagai berikut:

\section{Terbentur pada standar dan norma sosial tertentu}

Manusia pada dasarnya selalu menginginkan kehidupan yang sejahtera dan bahagia. Kehidupan yang demikian ini dapat terwujud bila kebutuhan fisik, biologis dan psikis mereka terpenuhi. Untuk itu, mereka berusaha memenuhi kebutuhan tersebut agar keinginannya terpenuhi. Akan tetapi, usaha tersebut seringkali tidak dapat mencapai hasil sebagaimana yamng diharapkan karena terhalang oleh adanya norma atau standar sosial yang harus mereka patuhi. Konsekwensinya mereka harus mengekangatau mengendalikan, bahkan menekan keinginan tersebut. Hal ini dapat menimbulkan tekanan batin karena adanya pertentangan antara keinginan untuk memenuhi kebutuhan, di satu sisi dan keharusan mengikuti norma-norma sosial di sisi yang lain. Sebagai contoh, nafsu seksual sebagai kebutuhan biologis selalu menuntut pemenuhan dengan cara melakukan hubungan seksual dengan lawan jenis. Akan tetapi kebutuhan tersebut tidak selalu dapat di penuhi, di antaranya, karena adanya norma-norma susila yang,mengatur bagaimana seseorang dapat melakukan hubungan tersebut. Adanya hambatan yang berupa norma norma tersebut dapat menyebabkan konflik batin, yang apabila tidak dapat teratasi dapat menimbulkan gangguan pada mental.

\section{Konflik Kebudayaan}

Konflik kebudayaan dapat timbul karena adanya interaksi dan saling mempengaruhi antara kondisi lingkungan dan sosial. Norma-norma modern, yang muncul sejalan dengan perkembangan ilmu pengetahuan dan tekhnologi, seringkali berbenturan (konflik) dengan norma-norma tradisional dan konvensional yang telah lama mapan. Keadaan yang demikian ini menyebabkan adanya kesulitan yang dihadapi oleh masyarakat untuk mencapai konsensus mengenai tata kehidupan dan norma keadilan. Benturan antar norma sosial tersebut dapat terjadi dalam bentuk konflik antara individu dan masyarakat, antara nilai dan perilaku, dan konflik batin dalam diri sendiri. Apabila konflik tersebut tidak dapat ditekan akan menimbulkan situasi yang menyulitkan dan

\footnotetext{
${ }^{4}$ Kartini Kartono,..........hlm. 30.
} 
menekan psikis manusia, yang konsekwensinya berpengaruh pada kesehatan mental mereka.

\section{Masa Transisi}

Perubahan yang cukup berarti yang seringkali terjadi dalam perjalanan sejarah Indonesia telah menimbulkan masa transisi. Masa transisi tersebut diantaranya terjadi pada masa hapusnya penjajahan yang diganti pada masa kemerdekaan, masa pergantian dari masa orde lama ke orde baru, dari orde baru ke masa reformasi sekarang ini, yang menuju ke era demokrasi. Dalam masa transisi tersebut banyak norma-norma sosial dan hukum lama yang tidak lagi sesuai dengan kondisi baru, sementara itu norma dan hukum baru belum muncul. Akibatnya, kontrol sosial dan pemberian sanksi menjadi kendur, dimana supremasi hukum tidak dapat ditegakkan, sementara penyalahgunaan wewenang dan kekuasaan meraja lela. Hal ini dapat menimbulkan ketegangan dan konflik yang terus menerus dapat menggangu mental masyarakat, yang pada gilirannya dapat menimbulkan permasalahan sosial dalam masyarakat.

\section{Meningkatnya Aspirasi Terhadap Kemewahan Material}

Masyarakat kita saat ini berada dalam kebudayaan modern yang bercirikan materialistik. Dalam budaya yang bercirikan demikian, materi menjadi ukuran kesuksessan hidup, sehingga semua individu berusaha untuk mencapainya. Hal ini juga didukung oleh pendidikan formal, maupun non formal yang secara praktis lebih diarahkan untuk meningkatkan standar kehidupan dan keseejahteraan masyarakat. Konsekwensi dari kehidupan yang materialistik ini menyebabkan kehidupan yang individualistik, mementingkan kesenangan diri sendiri. Dalam kehidupan yang demikian, kegagalan mencapai keinginan untuk mendapatkan materi telah menimbulkan tekanan jiwa, ketakutan dan kecemasan pada sebagian anggota masyarakat. Hal ini tentunya akan menimbulkan ketidak sehatan mental mereka, yang pada gilirannnya akan terefleksikan dalam masalah sosial yang mereka hadapi.

Apabila konflik-konflik batin yang ditimbulkan oleh faktor-faktor tersebut di atas berkembang dan berkelanjutran, maka akan timbul masalah sosial yang dihadapi individu atau kelompok masyarakat. Masalah sosial tersebut lebih banyak menimpa wanita daripada pria, baik yang masih sendirian maupun yang sudah berkeluarga. Hal ini terbukti dari kenyataan bahwa penghuni rumah sakit jiwa yang disebabkan oleh stress lebih banyak wanita daripa pria. Beratnya beban yang harus dipikul wanita modern, baik urusan domenstik maupun diluar rumah, menyebabkan kecapaian batin yang apabila tidak tersalurkan akan menjadi beban psikisnya yang tidak terpikulkan lagi. ${ }^{5}$ Akibatnya, apabila ketahanan psikisnya tidak kuat maka mereka akan mengalami ketidak sehatan mental.

\section{${ }^{5}$ Ibid, Hlm 88}




\section{Bentuk-bentuk Masalah Sosial}

Sebagaimana disebutkan di atas, dalam masa modern ini faktorfaktor yang dapat menyebabkan terjadinya masalah sosial semakin banyak. Masalah-masalah tersebut lebih banyak dihadapi oleh wanita karena meningkatnya beban hidup yang harus mereka tanggung. Diantara permasalahan sosial yang dihadapi oleh wanita adalah sebagai berikut;

\section{Kecemasan}

Kecemasan merupakan masalah sosial yang banyak dihadapi wanita di era modern ini. Hal ini terjadi karena para wanita berada dalam kehidupan masa depan. Ketidakmenentuan tersebut membuat mereka cemas, yang bila berkelanjutan akan menekan jiwa dan mengganggu kesehatan mental mereka. Tekanan dan gangguan tersebut dapat mempengaruhi perilaku sosial mereka, sehingga mereka akan mengalami kesulitan dalam berinteraksi sosial.

\section{Iri hati}

Iri hati merupakan suasana hati yang muncul sebagai respon terhadap kenikmatan yang diterima oleh oprang lain. Iri hati ini dapat dibedakan menjadi dua; positif dan negatif. Iri hati positif terjadi bila dalam menanggapi kenikmatanyang diterima orang lain tersebut sebagai suatu hal yang positif, bukan suatu yang dianggap merugikan,dan menjadikannya sebagai motifasi untuk meraih hal yang sama dengan cara yang benar. Orang yang iri hati positif dapat menerima kenikmatan sebagai hak penerimanya yang harus dihormati sehingga ia tidak berharap kinikmatan tersebut menjadi miliknya. Iri hati yang demikian tidak akan menjadi masalah sosial karena tidak mempengaruhi kesehatan mental. Sedang iri hati negatif terjadi bilaseseorang tidak dapat menerima orang lain mendapatkan kenikmatan sebagai kenyataan yang memang semestinya terjadi. Ia merasa bahwa kenikmatan tersebut seharusnya diterima oleh diriya sehingga ia tidak merasa senang. Perasaan tersebut seringkali juga mencerminkan dalam perilaku sosialnya sehigga dapat menimbulkan masalah dalam hubungan dengan orang lain. Masalah tersebut tidak hanya berdampak pada orang lain,tetapi terutama akan berakibat kurang pada mental yang bersangkutan.

\section{Takut}

Wanita modern banyak yang dihinggapi rasa ketakutan yang berlebihan dalam menghadapi kehidupannya.rasa takut tersebut seringkali muncul tanpa diketahui sebabnya sehingga sulit untuk mengatasinya. Bila rasa takut tersebut semakin menjadi-jadi, maka kehidupan bati yang bersangkutan tidak tenang, yang pada giliranya akan mencerminkan dalam perilakunya. Akibatnya wanita yang dalam keadaan demikian akan mengalami kesulitan dalam hubungan dengan orang lain. 


\section{Mudah tersinggung}

Tekanan batin yang menimpa seseorang menyebabkan ketidakseimbangan mentalnya yang dengan mudah dapat memicu emosinya dalam berhubungan dengan orang lain.ia dengan mudah menilai negatif terhadap perlakuan orang lain pada dirinya dan selanjutnya meresponya denagn emosional, yang seringkali tercermikan dalam perilaku negatif. Karena itu, sebagai rrespon balikorang lain akan menolak perilaku tersebut sehingga ia akan terisolasi dalam hubungan sosial. Akibatnya, ia akan mengalami kesulitan dalam berhubungan sosial dengan orang-orang disekitarnya.

\section{Over acting}

Seringkali wanita yang memiliki kelebihan, sepertikekayaan, kedudukan dan sebagainya, berperilaku yang tidak wajar, baik dalam tindakan maupun berbicara, dalam rangka untuk mendapatkan penghargaan atas kelibihannya tersebut. Perilaku yang tidak wajar (berlebihan atau over acting) tersebut dapat menyebabkan penolakan oleh orang-orang di sekitarnya dengan cara menjauhinya. Degan demikian, perilaku yang berlebihan tersebut dapat menyebabkan hubungan sosial yang kurang sehat sehingga akan memiliki masalah dalam pergaulannya.

\section{Agresif}

Agresif adalah kecenderungan seseorang untuk berusaha memaksakan kehendaknya pada orang lain. Hal ini terjadi karena yang bersangkutan terlalu egois sehingga menganggap bahwa orang lain harus menuruti kehendaknya. Untuk mewujudkan keinginannya tersebut ia memaksakannya pada orang lain. Apabila orang yang memiliki agrsifitas yang tinggi tidak mampu mengendalikan diri, maka ia akan mudah menyerang orang lain, baik dengan kata-kata atau penganiayaan secara fisik.akibatnya perilaku yang demikian, orang lain akan mengisolasinya dengan menghindari berhubungan denganya, yang pada gilirannya akan menyulitkan dirinya dalam hubungan sosial.

Semua masalah yang tersebut di atas dapat menyebabkan terputusnya komunikasi sosial dan disorientasi sosial. Apabila masalah twersebut cukup parah, maka wanita yang menghadapinya dapat mengalami stess, tekanan jiwa. Meskipun bersifat psikistress dapat mempengaruhi fisik karena adanya ketegangan saraf yang kemudian direfleksikan dalam gangguan fisik, seperti pusing kepala,baik menyeluruh maupun sebagian (migrain), diare, tidak selera makan, insomnia (sulit tidur) dan sakit lain yang tidak jelas penyebabnya. $^{6}$

Dari segi berat ringannya, masalah sosial dapat dibagi menjadi dua: ringan dan berat. Masalah sosial yang ringan adalah masalah sosial yang tidak sampai membuat orang (wanita) yang mengalaminya masih mau berinteraksi

\footnotetext{
${ }^{6}$ Kartini Kartono,....hlm. 276.
} 
sosial, bahkan sderingkali menjadikan kontak sosialnya sebagai ajang memngekspresikan ketidak sehatan mentalnya tersebut. Yang dapat digolongkan dalam kategori masalah sosial ringan adalah iri hati, cemas dan takut. Sedang masalah sosial berat adalah masalah sosial yang menyebabkan orang (wanita) yang mengalami sulit berkomunikasi dengan orang lain dan cenderung mengisolasi diri dan tertutup.

\section{Dakwah pada Wanita Bermasalah}

Dakwah merupakan usaha untuk mengajak orang lain ke arah ketaatan dengan berbuat yang ma'ruf (baik) dan mencegah terjadinya kemungkaran. Hal ini sesuai dengan firman Allah dalam surat Al-Ahzab (45-46); Hai Nabi! sesungguhnya kami mengutusmu untuk menjadi saksi dan pembawa kabar gembira dan pemberi peringatan, dan untuk menjadi da'I (penyeru) kepada agama Allah dengan izinnya,dan untuk menjadi cahaya yang memerangi." Meskipun yang tersurat dalan ayat tersebut ditujukan kepada Nabi, pengertian dakwah yang tersirat juga berlaku untuk para pengikutnya.

Secara teknis, Ibnu al-Qoyyim medefinisikan dakwah sebagai"menyeru kepada agama Allah, beribadah kepada-Nya, berma'rifat dan bermahabbah kepada-Nya"7 Pengertian tersebut di atas mengindikasikan bahwa Dakwah pada masa sekarang ini harus lebih diorientasikan untuk melakukan perbaikan masyarakat yang menghadapi masalah-masalah sosial, yang mencerminkan merajalelanya kemungkaran dan terabaikannya kewajiban-kewajiban oleh masyarakat. ${ }^{8}$ Dakwah diperlukan dalam rangka mengendalikan mereka ke jalan Allah agar dapat mencapai kebahagiaan di dunia dan akherat. Dalam kaitannya dengan usaha tersebut, setidaknya ada dua hal yang perlu diperhatikan oleh da'i agar proses Dakwahnya dapat berjalan secara efektif dan efesien, yaitu metode dan materi Dakwah. Meskipun komponen proses yang lain tidak kalah pentingnya, pembahasan berikut ini akan dibatasi dan difokuskan pada dua hal tersebut, meskipun tidak secara mendalam.

\section{Metode Dakwah Bagi Wanita Bermasalah}

Secara mendasar al-Qur'an telah menggariskan cara-cara atau metode Dakwah yang harus dipegangi oleh setiap da'i. Hal ini dapat kita jumpai dalam surat al-Nahl: 125. Ayat tersebut secara jelas menyatakan bahwa Dakwah, mengajak ke jalan Allah, dapat dilakukan dalam tiga cara, yaitu (1) hikmah atau bijaksana, (2) mau'idhah hasanah, dan (3) debat dengan cara yang baik. Dalam menafsirkan ayat tersebut di atas, Imam Syaukani mengartikan hikmah sebagai ucapan-ucapan yang tepat dan benar atau argumen-argumen yang tepat dan meyakinkan. Selanjutnya mau'idhah hasanah beliau artika sebagai ucapan yang berisi nasehat yang baik yang dapat bermanfaat bagi orang

\footnotetext{
${ }^{7}$ Ibnu al-Qoyyim, Fiqih Da'wah, hlm.29.

${ }^{8}$ Ibid, hlm.33.
} 
yang mendengarkannya atau argumen-argumen yang memuaskan, sehingga pihak yang mendengarkan dapat membenarkan apa yang disampaikan oleh pembawa argumen. Sedang debat dengan cara yang baik beliau artikan sebagai cara yang paling baik dari cara-cara berdiskusi. ${ }^{9}$

Sebagai suatu metode dakwah, manurut Sayyid Quthub, hikmah hasanah akan terwujud bila da'i yang menggunakan memperhatikan faktor berikut;

1. Keadaan atau kharakteristik orang yang didakwahi (mad'u), misalnya tingkat pendidikan, status sosial ekonomi, pola hidup dan sebagainya. Para da'i harus memahami mad'u mereka tidak dapat diperlakukan secara sama, tetapi harus diperlakukan secara berbeda.

2. Kadar / ukuran materi Dakwah yang akan disampaikan. Dalam hal ini materi tersebut harus sesuai dengan kesiapan mad'u agar tidak mengalami kesulitan dalam menangkap pesan Dakwah

3. Metode penyampaian Dakwah. Karena adanya perbedaan karakteristik mad'u, metode yang digunakan harus disesuaikan agar dapat mengena.

Sedang dalam menggunakan metode mau'idhah hasanah seorang da'i harus memperhatikan faktor berikut ini:

1. Tutur kata yang lembut sehingga akan mengesankan ke-hati-hatian da'i

2. Menghindari sikap kasar

3. Tidak menyebut-nyebut kesalahan yang dilakukan oleh mad'u, yang mungkin saja diakibatkan oleh ketidaktahuannya.

Selanjutnya dalam meggunakan metode mau'idhah hasanah, menurut Sayyid Quthub, seorang da'i harus memperhatikan faktor berikut ini:

1. Tidak merendahkan pihak lawan, apalagi menjelek-jelekkan sehingga ia yakin bahwa tujuan diskusi tersebut bukan untuk mendapatkan kemenangan

2. Tujuan diskusi hanya menunjukkan kebenaran yang sesuai dengan ajaran Allah, bukan yang lain

3. Tetap menghormati pihak lawan, yang harus diyakini memiliki harga diri, sehingga tidak akan ada perasaan kalah atau menang. ${ }^{10}$

Dalam rangka menggunakan ketiga metode tersebut untuk kelompok wanita bermasalah sosial, seorang da'i harus mempertimbangkan tingkat masalah sosial yang dihadapinya, sebagaimana dibahas sebelumnya. Untuk wanita yang mengalami masalah sosial ringan, yang masih mau berinteraksi sosial, dapat digunakan metode hikmah dalam bentuk ceramah. Untuk itu dapat dibentuk kelompok-kelompok kecil, yang disamping untuk memudahkan pelaksanaan, juga dapat untuk merekatkan ikatan sosial yang semakin

${ }^{9}$ Muhammad Ibn Ali al-Syaukani, Fath al-Qadir, Jilid III, Beirut: Dar al-Fikr, tt, hlm 203

${ }^{10}$ Ali Mustofa Ya'qub, Sejarah dan Metode Dakwah Nabi, ... Pustaka Firdaus, 1977, hlm 
melonggar dalam masyarakat industri saat ini. ${ }^{11}$ Dengan cara ini da'i tidak hanya dapat menyampaikan materi dakwah dengan mudah, tetapi juga dapat menciptakan kondisi sosial yang menghalangai berkembangnya masalah sosial yang dihadapi anggota kelompok. Konsekwensinya, tekanan batin yang dideritanya dapat berkurang, sehingga mereka tidak sampai mengalami ketidaksehatan mental.

Sedangkan untuk kelompok wanita yang mengalami masalah sosial berat yang sudah mengisolasi diri dari interaksi sosial lebih tepat digunakan metode mau'idhah hasanah. Karena terputusnya interaksi sosial, maka sebaiknya digunakan pendekatan yang bersifat individual dengan mengunjunginya. Menurut Arifin, ${ }^{12}$ teknik yang sesuai digunakan diantaranya adalah:

1. Wawancara. Teknik ini diperlukan untuk mengungkap fakta kejiwaan mad'u sebagaimana yang sebenarnya. Karena sifatnya yang personal, teknik dapat untuk menggali apa yang sebenarnya dirasakan dan dialaminya sehingga da'i dapat mencari jalan keluar serta menyampaikannya dengan nasehat yang tepat.

2. Direktif (bersifat mengarahkan). Teknik ini digunakan untuk mengarahkan mad'u agar berusaha menemukan penyebab dan mampu mengatasi kesulitan atau masalah sosial yang dihadapi. Teknik ini akan lebih berhasil bila melibatkan anggota keluarga lain.

\section{Materi Dakwah}

Karena tujuan utamanya adalah untuk mengajak mad'u ke jalan yang benar, yang diridloi Allah, maka materi dakwah harus bersumber dari sumber pokok ajaran Islam, yakni al-Qur'an dan hadits. Namun karena luasnya materi dari kedua sumber tersebut, maka perlu adanya pembatasan yang disesuaikan dengan kondisi mad'u, dalam hal ini adalah wanita yang bermasalah sosial.

Sebagaimana dibahas pada bagian terdahulu, permasalahan sosial muncul karena adanya ketidaksehatan mental pada wanita modern sebagai akibat dari adanya berbagai faktor yang tidak dapat mereka atasi. Karena pada dasarnya permasalahan sosial tersebut bagi yang mengalaminya lebih bersifat dan bersumber dari kondisi psikis, maka materi dakwah yang diberikan juga harus yang dapat menyentuh aspek psikis mad'u. penekanan perlu diberikan pada penyadaran tentang makna hidup didunia, yang hanya bersifat sementara, sedang kehidupan lain yang bersifat kekal masih akan dijalani setelah yang sementara ini berakhir.

Dengan demikian, diharapkan nantinya mad'u terbelenggu oleh kehidupan material yang menguasai era modern ini yang sebagaimana dibahas pada bagian terdahulu merupakan faktor utama yang berpengaruh pada

\footnotetext{
${ }^{11}$ Amrullah Ahmad, Islam dan Perubahan Sosial, ..., hlm 47

${ }^{12}$ H.M.Arifin, Pedoman Bimbingan dan Penyuluhan Agama, ... hlm 47
} 
tombulnya masalah sosial yang dihadapi wanita. Untuk itu, materi yang diberikan harus dapat memberikan ketenangan pada jiwa mad'u yang menghadapai masalah sosial. Karena itu, materi yang sesuai diantaranya, yang utama adalah yang berkenaan dengan hal-hal sebagai berikut:

\section{Keimanan dan Taqwa}

Iman merupakan dasar dari segala perilaku agar tidak menyimpang dari ajaran Allah. Dengan dasar iman, orang akan dengan mudah dan ringan melaksanakan ajaran agama, disamping menenangkan jiwa sehingga dapat menghindarkan dia dari faktor-faktor yang mempengaruhi kesehatan mental mereka. Hal ini sesuai dengan firman Allah dalam surat al-Ahqaf (ayat 13 dan 14) "Sesungguhnya mereka berkata: "Tuhan kami ialah Allah", kemudian teguh dan mantap hatinya. Maka tiada rasa takut yang menimpa meraka dan petunjuk bahwa hanya dengan iman kepada Allah, ketakutan dan kegelisahan batin akan dapat diatasi sehingga kesehatan mentalnya tidak akan terganggu."

\section{Tawakkal}

Tawakal adalah menyerahkan diri kepada Allah atas usah yang telah dilakukannya dengan sekuat tenaganya. Hal ini tidak berarti bahwa seseorang hanya menyerahkan segala sesuatunya kepada Allah tanpa disertai usaha apapun. Akan tetapi, tawakal harus didahului dengan usaha maksimal seraya memohon pertolongan dari Allah agar usahanya berhasil. Namun demikian, ia menyerahkan sepenuhnya akan apa yang ia terima dari usahanya tersebut atas dasar keyakinan bahwa penentu terakhir atas keberhasilannya adalah Allah.

Dengan tawakal ini, ia akan dapat menerima apapun hasil yang diperolehnya sehingga tidak akan tertekan batinnya, meskipun mungkin bertentangan dengan harapannya. Dengan kondisi mental yang demikian, ia akan terhindar dari masalah sosial yang bersumber dari jiwanya terasebut. Hal ini sesuai dengan firman-Nya "Dan barang siapa menyerahkan diri kepada Allah dan berbuat kebaikan, maka sesungguhnya ia telah berpegang pada tali yang maha teguh". Dengan tawakal ini ia akan terbebas dari beban psikis yang dapat menganggu kesehatan mentalnya.

\section{Qana'ah}

Qana'ah berarti menerima dengan senang hati segala sesuatu yang telah diberikan oleh Allah kepadanya dan menikmatinya secara wajar. Hal ini bukan berarti bahwa ia cukup merasa puas dengan apa adanya dan menghentikan usahanya tersebut sebagai suatu nikmat yang harus disyukuri. Dengan rasa qana'ah, seseorang tidak akan menjadikan materi sebagai tujuan dari hidupnya, tetapi hanya sekedar sebagai alat menjalani hidup ini. Karena itu, ia bisa terhindar dari tekanan jiwa yang dapat menyebabkan munculnya berbagai masalah sosial, seperti iri hati yang negatif. 


\section{E. Kesimpulan}

Kehidupan modern telah banyak memberikan manfaat bagi kehidupan manusia. namun demikian, disisi lain kehidupan tersebut juga memiliki dampak negatif, terutama bagi wanita, dengan adanya tekanan (konflik) batin akibat perubahan peran sosialnya dan orientasi kehidupannya. Tekanan batin tersebut sangat berpengaruh pada kesehatan mentalnya, yang pada gilirannya menyebabkan timbulnya masalah sosial sehingga mengganggu dalam interaksinya dengan orang lain. Dakwah, yang mempunyai tujuan mengajaknya kepada jalan hidup yang benar, diharapkan dapat membantu wanita mengatasi masalah sosial yang dihadapinya tersebut. Agar berhasil, Dakwah yang dilakukan harus menggunakan metode dan materi yang sesuai dengan kondisi mad'u, yang dapat menghindarkan atau mengurangi tekanan batin dalam menghadapi kehidupan di era modern ini. Untuk itu, da'i harus berpegang pada metode dan materi Dakwah yang telah digariskan oleh alQur'an dan hadits. 


\section{DAFTAR PUSTAKA}

Ahmad, Amrullah, Islam dan Perubahan Sosial, Bandung: Mandarmaju, 1992.

al-Qoyyim, Ibnu, Fiqih Da'wah, Jakarta: Raja Grafindo, 2000.

Al-Syaukani, Muhammad Ibn Ali, Fath al-Qadir, Jilid III, Beirut: Dar al- Fikr.

Arifin, H.M, Pedoman Bimbingan dan Penyuluhan Agama, Jakarta: Raja Grafindo, 1998.

Clave, Julia, Gender dan Pembangunan, Yogyakarta: Pustaka Pelajar, 1996

Kartono, Kartini dan Jenny Andani, Hygiene dan Kesehatan Mental dalam Islam, Bandung: Mandar Maju, 2004.

Rahmat, Djalaludin, Islam Aktual, Bandung: Mizan, 1984.

Ya'qub, Ali Mustofa, Sejarah dan Metode Dakwah Nabi, Jakarta: Pustaka Firdaus, 1977. 